\title{
Almost a Teacher: Considering Curriculum Through Reflexion in the Liminal Space
}

\author{
Sherry Martens \\ Ambrose University \\ Craig Harding \\ Ambrose University
}

This article examines the liminal space, "the betwixt and between" (V. Turner, 1969), that preservice teachers inhabit after they complete their last practicum and return to campus for final coursework. We look at preservice teachers' expectations, assumptions, and understandings of questions and content in a senior-level curriculum course as uncovered through their assignment, the commonplace book. In this assignment they examined their understanding and meaning-making, or "truth-telling" (Huebner, 1999), in a personal text, which can allow for continued practice of reflection and reflexivity as they enter into their careers in addition to informing the researchers about how students experience growth in their understanding of issues in curriculum as experienced in the liminal space, grounded in historical, social, cultural, and experiential contexts.

Keywords: teacher education, curriculum, liminality, reflexivity

\section{INTRODUCTION}

Honor the space between no longer and not yet. (Levin, n.d., para. 6)

After long careers in public schools, we were provided with a new opportunity to use our classroom experiences and academic backgrounds. Teaching full-time in an education program seemed like a natural progression. Our combined experiences span teaching in $\mathrm{K}-12$ settings, teaching undergraduate and graduate courses in faculties of education, and holding various administrative roles in schools and district offices. These experiences shaped our own stories - they created a reality in which we felt a familiarity yet continually sought to grow. However, by assuming new roles in postsecondary, we began a different journey, uncertain if practical experience or academic knowledge was more important. Not solely technicians of teaching and not yet scholars immersed in research,we found ourselves in a space of transition. We soon joined our students in movement through a liminal space.

Liminal space is an anthropological concept articulated by Arnold Van Gennep (1909) over one hundred years ago while studying religious rites of passage in tribal societies. Victor Turner (1969) then extended Van Gennep's model to other disciplines, including sociology. As Singh (2020) explained: 
The liminal phase in a rite of passage is analogous to being stripped of all the identity markers that ties a person to a particular segment of society, and being suspended between two worlds for a period of time: the world left behind and the world one is being shaped for. It is similar to traversing through a no-man's land where there is very little that can be seen ahead. (p. 114)

This notion of "the betwixt and between" (V. Turner, 1969) has provided a useful heuristic for examining diverse sites and periods of transition or change ranging from pregnancy, illness, entry into postsecondary education and other educational endeavors (Willson, 2019).

In Betwixt and Between: The Liminal Imagination, Education and Democracy, James Conroy (2004) offered more nuance to the notion of liminal space, describing it as the "intellectual, cultural, and ideological spaces that ... [exist] on the margins, neither centre nor on the outside" (pp. 7-8). Envisioning liminality as a momentary encounter, he argued that thoughts, reflections, and engagements arise from close encounters with texts, ideas, and colleagues to create what Todd (2014) called "a horizon of possibilities that guides teachers' educational work" (p. 235). Thus, while liminality emphasizes social construction of understanding or coming to know, growth requires conscious awarend of what is necessary. Todd (2014) explained that this liminal imagination becomes "both an orientation to teaching and education at the same time as it calls forth an alternative mode to theorizing education" (p. 236).

It became obvious for both of us that the formation of our undergraduate students was different from what we had previously experienced as teachers in $\mathrm{K}-12$ schools. In schools, we built upon a prescriptive curriculum that endeavored to create, after 13 years of growth, a well-rounded, educated student who would assume a productive role in society. In a 2-year education after-degree program at Ambrose University in Calgary, Canada, students were instead in a condensed state of becoming. They inhabited a space different from typical subject matter undergraduate programs. In an education after-program, they must develop academic understanding of curriculum, educational philosophies, learning theory, legal imperatives, and unique tenets of sociology that will be put into action during their practicum experiences. Combining this knowledge and wisdom in preparation to teach an unknown class undetermined content in an unknown context creates a unique transitional space — one that "requires a language of in-betweenness, or liminality, that gives full weight to the complex processes of human becoming" (Todd, 2014, p. 234).

While their practicum experience constitutes one phase of a macroliminal space, students often perceive completion of their final practicum as the culminating step in an apprenticeship model. Consequently, postpracticum courses are an ideal (and necessary) setting to encourage continued growth and progress in the final phase of being betwixt and between. Students are no longer just learners of theory and pragmatic information. They are in the final stages of becoming credentialed practitioners or professionals. Simply inhabiting this space does not induce a final transformation. Transformation, or becoming, requires them to actively shirt - reflectively and reflexively - from the values, actions, and routines of their first foundational year of the 2-year program and their extended practica while engaging in a final stage of exploring the culture of teaching. Conroy (2004) explained that during this postpracticum moment students need to wrestle with the vagueness and imprecision of concepts and structures of education that are often formulated and reconciled outside the formal deliberations of the education classroom. Thus, this unique time for preservice teachers offered us, the course instructors, an opportunity to disrupt and challenge the preconceived transformative process of theory building courses, practicum experience, and graduation.

Beard and Wilson (2006) and Lutterman-Aguilar and Gingerich (2002) explained that this transformation is explicitly related to the ability of instructors to create an environment that understands and mirrors desirable growth in a learning continuum. Consequently, we sought to unsettle preconceived expectations, assumptions, and understandings of questions and content through a senior-level course, Synthesis of Principles and Practices in Curriculum Design and Program Development (CDPD 700), as uncovered in a commonplace book assignment. Originally derived from the Latin locus communismeaning "common in our living space"- the commonplace book is a provocative space that allows students to question, reflect on, and act reflexively in regards to course content in order to encourage deeper personal observations. Dacome (2004) noted, "Regarded as aids to memory and storehouses of knowledge, they 
were part of a pedagogic tradition related to rhetoric and the art of memory that dated back to the classical period.... [Commonplace books were] tools that lay at the intersection between practices of collecting, reading, classifying, learning and the arts of rhetoric" (pp. 603-604). Eddy (2010) added that commonplace books or "commonplacing" were an opportunity to record thematic topical logic, which moved from a rehearsed position in classical times to later being guided by the training and ideas of the individual.

In our course, these actions of reflection and reflexion involved navigation through a liminal space where the postpracticum student entered professing that they already knew how to teach or recognizing what they did not know. The opportunity to record thoughts, observations, quotes, and readings that appeared unrelated in isolation revealed an examination of understanding and meaning-making by preservice teachers of language as "truth-telling" (Huebner, 1999). We introduced the commonplace assignment to provide a place for students to write, represent, or speak to make sense of this in-between space in which they now found themselves. We wanted them to understand that this was not just a place to reflect and tell us what they thought we wanted to hear, reminiscent of "commonplacing," but rather the final place to grapple with all that they were contemplating as their program was coming to a close. As the entries were kept between us and the preservice teacher, we encouraged honesty and openness, having already built a trusting relationship with them over the course of 2 years. We were also interested to see how they might take this opportunity to give themselves over to the process of considering curriculum in the course and ask themselves what they did not see and did not know rather than reflecting on what they did. How then might we understand how students experienced the liminal space through a hermeneutic lens?

According to the philosophical hermeneutics of Hans-Georg Gadamer (2004), people speak to understand, and it is because they are oriented to the world as understanding beings that they are always in dialogue with it. David Smith (1999) wrote, "Understanding is itself not a fixed category but rather it stands for a deep sense that something has been profoundly heard in our present circumstances" (p. 42). This means that hermeneutical consciousness is always and everywhere a historical consciousness, a way of thinking and acting with an acute awareness of the storied nature of human experience. Hermeneutics is not a methodology but a living tradition of interpretation with a rich legacy of theory, philosophy, and practice. Although it is not a method, Jardine (2006) noted that hermeneutics

does give researchers, and teachers and students, an image of how human understanding operates in the world. It articulates how the world is a living world of living ancestry that perennially has to take up the task presented by the arrival of the new and the young into the living world ... it provides a way to re-think what we experience in our day to day lives as teachers ... what we understand knowledge and tradition and language and conversation and art and play and imagination and words and images and the methods of the sciences to be. (p. 269)

As professors of the course, we were not merely observers of our students, apart from their learning, we were in the midst of the liminal space with them, utilizing the text of the commonplace book as both a way to understand each student's experience of liminality and to understand the impact of our disruption in this betwixt-and-between space. The commonplace book also offered an understanding of the scope for opportunities. Gadamer (2004) argued for approaching "the art of writing in such a way that the thoughts of the reader are stimulated and held in productive movement" (p. 395), which "consists entirely of being drawn into a course of thought. The art of writing ... does not try to be understood and noticed as such" (p. 395). Thus, we could read the commonplace entries and experience liminal space itself, not just the experiences of the writer. Furthermore, Gadamer wrote:

What is stated in the text must be detached from all contingent factors and grasped in its full ideality, in which alone it has validity. Thus, precisely because it entirely detaches the sense of what is said from the person saying it, the written word makes the understanding 
reader the arbiter of its claim to truth. The reader experiences what is addressed to him and what he understands in opinion; is always possible truth. (2004, p. 396)

Drawing from the work of van Gennep (1909), Victor Turner (1974) described the phase of transition in a rite of passage as a time of ambiguity, which he refers to as "limen" (p. 57). Reflecting on Singh's (2020) idea that "a liminal phase ... is analogous to being stripped of all of the identity markers ... being suspended between two worlds for a period of time ... where there is very little that can be seen ahead" (p. 114), we wondered if this was the case for students who, for months, had been elevated to the position of teacher but now returned to the classroom as student. Etymologically, "liminality" refers to a threshold. How was this idea of a threshold, a point of reentering the world of teaching that they were being shaped for, experienced by the students? How did they interpret the impact of learning about curriculum as a way to make sense of the ambiguity of the liminal space?

\section{ENTERING THE LIMINAL SPACE: LISTENING TO THE STUDENTS' VOICES}

The major point of this course was to recognize and understand that we need to explore the uncomfortable to learn. Learning is a messy subject, and we need to be alright with the mess. (Jane, student, 2020)

The BEd Elementary (After-Degree) at Ambrose University integrates four streams - curriculum, learning theory, history/philosophy and field experience - through shared praxis. Students move in and out of schools as both observer and preservice teacher while they take up theory in practice on campus. They are asked to consider their evolving identity as a preservice teacher in the context of what they are learning. In their second year, the students begin in September in a school setting. They return to campus after 4 weeks for two courses while still going out to their schools one day per week and then return to practicum full-time in January for 6 weeks. Upon completion of these experiences, they have been part of a school community that identified them as a teacher for 5 months. We are always excited to welcome the students back to campus. They always arrive with a mix of regret and sadness at leaving "their" students, and often they feel agnostic and apathetic about to what comes next, because they already perceive themselves as finished teachers.

Teaching is unlike any profession, we tell our students, who come with up to 13,000 hours of experience as students in a K-12 setting. Britzman (2003) described this as a "school biography":

Newcomers feel the force of their own history of learning as if it telegraphs relevancy to their work ... over-familiarity animates the fantasy that no one can teach anyone to become a teacher, each must learn his or her own way. Theoretical knowledge of teaching is not easily valued and school biography matters too much. (p. 1)

We have only 2 years in the program to unpack and reorient our students as teachers.

There is another biography that we hear in the liminal space, and that is how students continue to craft their philosophy of teaching and what they will value and emphasize as they enter the profession. It is during this class, in the commonplace, that assumptions culminating from their combined school biographies from their prior experiences as well as those from their practicum are exposed and discussed. Britzman (2003) stated that "there is no single story of learning to teach. There are, however, shared persistent dilemmas, contradictory realities, and common narratives that the newly arrived personally confront and internalize as their own" (p. 6). Helen (a pseudonym), one of our students, explained:

Throughout the semester, my thinking was continually challenged and revised, thanks to the readings and process of thought that I employed. Rather than just taking away key points, I was critically thinking and questioning the ideas proposed ... as well as the ideas I had from prior experiences. The commonplace book documents my journey not only from 
the readings but a development of responses to the articles and classroom discussions throughout the term. I found that I became aware of my blind spots ... and learned to be a more empathetic teacher in and out of the classroom. Initially, my first post was all about me and what I thought. I find it interesting that my thoughts in the end were about others, and how they may be affected by the changes in education, particularly, I acknowledge my prejudice and began confronting the ideas that I had created in my own mind.... I believed what I thought I knew... I have talked about how I am personally motivated by grades and my parents liked to see my grades as I grew up. After reading and listening, I began questioning if students (from the area I did practicum) experienced the same self and parental motivations. Although I thought that I would be an adamant grader in my classroom, I questioned that thought in my commonplace because it is not about me when I am in the classroom. My ways need to be flexible so that I can deliver the curriculum as lived rather than as planned.

Britzman (2003) suggested that the act of becoming a teacher may be considered through the "voices" and how preservice educators listened to or took up the voices presented. For Helen, we wondered if her shift in how she saw herself throughout the course was a now more predominant voice that "was used to signify something unique in the individual, such as finding one's real voice, but it also meant encountering even more contradictory realities on the way to self-definition ... this version suggests a struggle for voice, finding the words, feeling heard" (Britzman, 2003, p. 17).

Zoe, another student, also grappled with how the readings and discussions interrupted her own evolving identity as an emerging teacher:

The readings and discussion about privilege challenge, provoke and exhaust me all at the same time. I am a conscientious person who feels like this label [privileged] carries with it the connotation of being undeserving, or unworthy of my accomplishments as a white female. This is troublesome to me. As Michele Tanaka explores in her book, Learning and Teaching Together (2016), this constant and reflexive examination, “...causes uneasiness among teacher educators as it asks that they pay attention through silence, deep listening and observing; it requires openness to exposing personal feelings and the possibility of critique". I feel it is a fine balance....

Each story has its unique circumstances and what I witnessed does not hold true for all. Each story is worthy of being heard through a lens that is not colored by my experiences, but in the context of that individual's reality-with empathy, understanding and no judgement... I will always come back to examination of self in the humble pursuit of how I can best serve my students. At 39 years of age, I had few regrets about my life choices.

I ventured away from a comfortable path so that I could be "disturbed" and my ideas challenged and that is what I have been exposed to at Ambrose. Whether it was how I looked at assessment, how I looked at inherent biases in myself or how I looked (over looked) at the variables involved in uncovering each student's true potential, I have been constantly provoked and pushed to look at the world through a different lens. It is a daunting challenge and I am aware of the vulnerability it requires to take that challenge on. I could have stayed in my bubble, my comfy life, one of little resistance and challenge. Had I stayed in my place of comfort, I would always have been left with the wonders that I want each and every one of my students to know as fact: only through courage, curiosity, faith, humility and hard work can we truly discover what lies within each and every one of us.

Both Helen and Zoe were describing what Britzman (2003) referred to as the third voice: 
When we learn to teach, we are also trying to make from this uncertainty, narratives of education: our own and those of others. It is not just that we must put into words how we think about our learning, although this activity is what teachers ask of their students and theoretically should be able to ask themselves. The existential tension is that just as we try to make from our learning a narrative of what we think has happened, we are also learning the happenstance of narrative. We try out a series of story lines that may or not be acceptable, useful, or intelligible to us and to those who surround us. Yet these narratives of learning are not just overlaid upon a pre-existing experience; they are constitutive of experience itself. (p. 20)

Britzman's (2003) notion of trying out different storylines in an experience-based narrative was made explicit in a final commonplace synthesis written by our student Moira:

Upon reflections on the readings and discussions in class over the past few weeks, I found myself questioning who I am as a pre-service teacher. In my mind, I always thought I would be a teacher who builds relationships with each student and focuses on each child's need to foster trust, mutual respect and growth in my students. This week, I began to wonder if this idea was less attainable than I thought. As I approach the end of my own education program, I am questioning the tools and skills I have and are they enough to allow me to thrive in the diverse encounters with learners, parents and peers while maintaining an open mind, free of judgements? Will I be able to listen with a heart to understand first?

In the article titled "On the Epistemology of Reflective Practice", Max van Manen outlines the importance of reflecting on our practices to recognize and distinguish between what is good or appropriate and what is bad or inappropriate for each student in the classroom. Max restates Dewey's argument that reflection resulted in an educator feeling perplexed or confused, followed by attempting to understand the situation, assess and analyse various considerations, and finally decide on a plan of action. To do this, Dewey stated that an educator required the following characteristics: An open-mind, sincerity, interest, responsibility and thinking in a reflective way. Over the past two years, I have acquired knowledge and theories of classroom management, effective teaching and assessment methods, as well as criteria identifying student needs and utilizing strategies to enhance learning in the classroom.

Having this knowledge gave me confidence to start my practicum this year with assurance I was capable of teaching my class effectively. What I did not plan for though were the bumps along the way.What is apparent to me now is that I need to hear the full story or numerous stories before I can decide which tool to pull out of the toolbox and how to apply that tool. I need to focus on keeping an open mind, to be sincere and apply periodic selfassessment to ensure I build authentic relationships in my classroom.

\section{WHAT ARE WE TO MAKE OF THIS?}

It would be nice to be able to tie up the course with a neat bow and report that students come out fully formed on the other side of the liminal space. They don't. We discovered that for our students, much like ourselves, more questions and uncertainties remain than are resolved. But we understand that we are always evolving, changing, and moving forward. As our student Colin observed in his commonplace book, "While to some extent, reflection involves allowing our beliefs to be challenged, I believe few people, including myself, relish the cognitive dissonance that comes with realizing you have been wrong about something."

In Colin's comment, we see the liminal space has evoked a sense of periagoge for students. Periagoge is an idea that emerged from Plato's allegory of the cave, where prisoners held in a cave are misled to 
believe the shadow puppets they see reflect the real world. It is not until one prisoner escapes that they realize there is a new uncomfortable world beyond their limited experience. For Plato, the allegory illustrates that the real world lies beyond people's naïve conceptions and can only be understood when challenged intellectually. This new understanding was referred to by Socrates as periagoge - a "turning around of the soul." Trepanier (2015) explained that periagoge requires "a heightened awareness and openness" (para. 6) and the need to "step outside of narrow confines of self-interest" (para. 6). Or, as Beverly stated, "I must as a teacher, fracture my narcissism." For educators, this implies that knowledge of the real world - the classroom - cannot simply be taught but requires teachers to direct students to alternatives that provoke reconsideration of existing naïve conceptions of what is real.

While it is impossible to represent the voices of all our students, the use of rhetorical questions and phrases such as "This idea raised lots of questions for me..." or "I honestly hadn't considered..." were prevalent. A representative example that explicitly illustrates a "turning of the soul" is provided by Zoe, who explained how being challenged and developing a heightened awareness and being open in the liminal space creates a sense of uncertainty and confusion leading to periagoge:

Understanding my privilege and inherent biases that come with it has also been an awakening for me. Once I could work through some of the guilt that my privilege brought with it, I was able to see how it impacted the lense through which I looked at everything from homework, to assessment, to technology, to relationships - the thing I value the most of all. It has been so interesting to me to step out of my bubble, look at the world through a different lense then to come back to people that hold the same beliefs I used to hold, and still exercise empathy knowing that had it not been for this program, I would still view the world through that same narrow lens.

Yet heightened awareness alone does not provide definitive solutions. Instead, it creates new conundrums for future consideration. Ellen exemplified this idea by reflecting that she "felt conflicted when Black and Wiliam (1998) pointed out that teachers are often unaware of the focus they are placing on grades and summative assessment, even when they know that it does not produce deep learning in students (p.4)." She asked, "How will I as a growing teacher not let the temptation to teach to the test seep into my philosophical foundations?" Rather than accepting that periagoge within the liminal space should be the result of a prescriptive curriculum that is monolithically experienced by all inhabitants, the liminal space should be viewed as dynamic and responsive and requiring room to allow for reflective questioning and reflexive action on an altered positionality_-periagoge - based on what individuals now come to know as they travel through the liminal space (Cook-Sather, 2006).

Applying Lonergan's (1957/1992) notion of insights to learning in a liminal space shows the fecundity of such an environment. Lonergan sought to explore how people came to understand something. Heading and Laughlin (2018) explained that Lonergan "does not view learning as an acquisition of something, as a gain in knowledge per se, but as a dynamic process of coming to understand, and, as such, a process which itself can be understood by the human agent" (p. 660). This socially constructed perspective sees learning as "highly personal, to the point that even if two people have the same initial experience, their focus, questions, insights, concepts and judgments are formed in their individual contexts and their insights will not be exactly the same" (Heading \& Laughlin, 2018, p. 662). As our student Karolyn stated, "Learning and teaching are complex, and I am discovering that there are many layers to unpack." She explained that common place reflections had brought changes for her: "I'm not sure if the commonplace book has allowed me to see things more clearly or if it has pushed my thinking, shown me how messy and interconnected these concepts can be and brought up more questions and wonderings."

Karolyn's comments reflect Lonergan's (1957/1992) idea of a circular and reflexive interconnectivity between various insights that, once established, lead to individually contextual judgments, often unrelated to the ones held by those with whom the experience was shared. Consequently, students develop a more nuanced consideration of education and the impact of their personal values on future practice. In the program at Ambrose University, we also seek to interrogate each preservice teacher's understanding of who 
they are in the midst of becoming a teacher. This continual disruption and personal "coming to know" represents learning - an act that effectively takes place in a liminal space in which each insight is considered within the cumulative context of other insights. The result is a richly conceived idea or concept developed by the learner, one that can be tentatively considered rather than just simply accepted (Heading \& Laughlin, 2018).

Conroy (2004) argued that teachers, and by extension preservice teachers, need to recognize the possibilities that dialogic discourse offers, as "much of human thought, reflection, and engagement with the world emerges out of the cracks and fissures of our personal relations and not in the wide-open structured spaces" (p. 62). In our liminal space, periagoge was explicitly facilitated by dialogic encounters with classmates. This required an openness and willingness to step outside the narrow confines of selfinterest in order to develop a tentative understanding of truth. Returning to Colin's comments, we can see he implicitly invokes the allegory of the cave and the dissonance of periagoge"

As a "veteran" pre-service teacher, I had reached some definite beliefs about knowledge (epistemological realism) and teaching and learning, such as Rosenshine's (20212) [sic] principles of instruction. The requirement, then, to read Aoki (1993), who quotes Jean Francois Lyotard, and Freire, an outspoken Marxist, was like spending type with my archnemeses of those whom I had sworn allegiance - the likes of W.C. Bagley and E.D. Hirsch. Although I was not converted by the critical theorists ... I could at least see how they were honestly trying to find answers to the same problems as others with whom I agreed ... causing me to question what I thought I knew....

While I try to maintain a degree of intellectual humility, I did begin the course with a kind of certainty about what was important to know and what I could comfortably ignore, so I balked at the idea of having to re-examine everything up to that point to see if I could identify holes in my logic or wrinkles in my theories. Not only is it inconvenient to do so, but I recognized, ironically, that I have also developed a deep skepticism towards postmodern skepticism. To be asked to use such a tool to critically assess my beautifully adorned sacred cows was uncomfortable, to say the least... Nevertheless, I felt as though I could enter the fray, go through the exercises, and emerge unscathed. To have to admit then, that I came away with some edges worn off and a chip missing from my shoulder was a loss.

While periagoge for Colin was more philosophical, for other students it was more practical or real world. Upon reading and engaging in small group discussion on an article, Karlie noted,

When we came up against confusion and uncertainty our lens to interpret what's going on and our explanations within our beliefs no longer work. This is when we question our preconceived beliefs.... I see connections in my own growth and learning while being in a place of "knowing while not knowing" rather than being stuck in my own certainty.... Uncertainty and confusion create opportunities for growth and change by allowing a greater sense of empathy, awareness and reflective thinking.

For some students, periagoge proved to be an uplifting and regenerative act. The expectations that completing their final practicum simply required them to be a well-prepared education technician relying upon immaculately prepared lessons was shattered during their 6-week experience. They returned confused and disheartened. The readings and dialogic encounters within the liminal space provided a venue for students to come to a shared realization that in the real world, teaching and learning is, as Jane noted, "messy and we need to be alright with this messy." For some, a subtle readjustment and awareness were all that was needed. Periagoge can provide this, as described by Plato (cited in von Heyking, 2017): 
Then there would be an art to this very thing ... this turning around (tes periagoges), having to do with the way the soul would be most easily and effectively redirected (metastrophe), not an art of implanting sight in it, but of how to contrive that for someone who has sight, but doesn't have it turned the right way or looking at what it needs to" (para. 4).

Students came to accept Britzman's (2007) idea that teacher education is best conceived as an unfinished project in which they accept "responsibility for the discomforting fact of our dependency on the unknown" (p. 12). Thus, periagoge remains incomplete-a desirable trait for the lifelong learner. Colin concurred, noting, "More than anything, I have come to accept that there is not one right way to do something, but rather, and [sic] endless list of inspiring, eye-catching or overlook[ed], developing or timeless ways of teaching effectively." Kathryn commiserated:

Working on the commonplace book has provided me with the space to collect my questions, comments, connections and ideas about our readings and discussion in CDPD 700. The most apparent key idea that resurfaces throughout the book is the concept of identity in teaching. I have come to understand that as teachers, our values and beliefs are an integral part of our teaching as we decide what fits for us and what doesn't.

Our identity affects who we are and how we behave. It affects our ability to connect with others, and it can lead to basis, expectations, blind spots and assumptions. Many of the readings from this course point out that there is a vulnerability in digging into our identities and that is in constant throes of production. The concept of identity is connected to developing awareness of ourselves through ongoing reflections. Many connections in my commonplace writing were made to Wheatley's notion about difficulty in giving up our uncertainty. When we come up against confusion and uncertainty, our lens to interpret what's going on and our explanations within our beliefs no longer work. This is when we question our preconceived beliefs.

I see connections in my own growth and learning while being in a place of "knowing while not knowing" rather than being stuck in my own certainty. I think that I was initially uncomfortable with this feeling, especially during my practicum, because it was not a familiar or safe feeling in my previous learning experiences. I have come to see how uncertainty is an important component to learning but also to building close relationships by listening to differences and seeking to understand others without being stuck in judgement. Uncertainty and confusion create opportunities for growth and change by allowing for a greater sense of empathy, awareness and reflective thinking. Learning and teaching are complex, and I am discovering that there are many layers to unpack. I'm not sure if the commonplace book has allowed me to see things more clearly or if it has pushed my thinking, shown me how messy and interconnected these concepts can bring up more questions and wonders. Either way, I have enjoyed the readings and discussions and have become more comfortable with my uncertainty as I continue to learn and grow.

Fortunately, the complexity and unsettled experiences of the liminal space do not occur in isolation. Victor Turner (1969) used the term "communitas"- derived from "community," which implies fellowship and partnership - to describe those who share the common liminal space and the bonds or interconnections that unite them. For him, liminal spaces develop a strong sense of "humankindness" between inhabitants, creating the potential for the development of communitas. Edith Turner (2012) noted that communitas is a natural process in which any sort of hierarchy is flattened and commonalities are recognized yet individual talents, dispositions, and contributions are honored. A cohort model, such as what is in place at Ambrose University, assumes that there is value in the interactions and support of a group and that as students enter courses with a range of shared experiences, the bridges and bonds needed for the development of 
communitas already exist. The natural process of communitas is further enhanced by dialogic discourse or encounters with fellow inhabitants of the liminal space who "are shaped as they shape each other in the process of coming to know" (Britzman, 2007, pp. 25-26). Britzman (2007) added that "these dialogic relations determine the very texture of teaching and the possibilities that it opens" (p. 27). Yet to best develop this discursive discourse within the physical and psychological space of a cohort, all community members are required to spend personal time and energy to create true communitas. It is within this community that the instructor as provocateur can provide disruptive experiences that push students to break free from their postpracticum complacency and seek deeper understanding of the nature of teaching through the reflective process.

Teacher education represents a conundrum for preservice teachers. Students have been enticed into a teaching career because of previous positive experiences in education and look back, often nostalgically or romantically, at these experiences. They have preconceived ideas and archives about what schooling should and should not look like:

Growing up in education permeates our meanings of education and learning.... It makes us suspicious of what we have not experienced and lends nostalgia to what has been missed. Simply put, our sense of self and our sense of the world is profoundly affected by having to grow up in school. And this means that both the experience we have and the having of experience are problems of education. (Britzman, 2003, p. 6)

By viewing the final postpracticum courses of an education degree as a liminal space that seeks to encourage periagoge, we sought to encourage tentative resolution of these conundrums through phronesis or " 'practical wisdom' that has been derived from learning and evidence of practical things. Phronesis leads to breakthrough thinking and creativity and enables the individual to discern and make good judgements about what is the right thing to do in a situation" (Oxford Review, n.d., para. 1). These resolutions or "coming to know" are not prescriptive yet provide the "horizon of possibilities that guides teachers' educational work" (Todd, 2014, p. 235). When transitioning within the liminal space and wrestling with conundrums, students realize that their periagoge may differ substantially from their colleagues, as alternative modes and orientations to education can emerge in a time of social construction of understanding. "There is discomfort in critical reflections because there is vulnerability," explained Karolyn.

In considering what inhabiting the liminal space of "not yet a teacher" does to preservice teachers, our concern is with how the activity of taking apart teaching and, in doing so, taking apart themselves as almostteachers, demonstrates something about the subjectivities of teachers and determines ways teachers come to construct their teaching identities. The commonplace book allows for a place that reflects

the tensions between knowing and being, thought and action, theory and practice, knowledge and experience, the technical and the existential, the objective and the subjective. Traditionally expressed as dichotomies, these relationships are not nearly so neat and or binary. They fashion as well the ways teachers understand their practices and the subjectivity that bestows this practice and the teacher's identity is part of the hidden work of learning to teach. This unmapped territory, then, must be charted in ways that can permit a double consciousness of how systemic constraints become lived as individual dilemmas. (Britzman, 2003, pp. 25-26)

As change in a liminal space will be experienced differently by each of its inhabitants, it would be expected that the betwixt-and-between experience would be muddled, confusing, and untidy-or, once again citing Jane, messy. The liminal space, much like a garden, is a fertile space for growth, but there is a need to turn over the soil for regeneration. Victor Turner (1981) acknowledged that this turning over or disruption of the foundations developed in prior courses and experiences creates a sense of instability and tension within the liminal space: "The schemata that give sense and order to everyday life no longer apply 
but are, as it were, suspended" (p. 161). Yet the reconsideration of new insights can create a sense of exhilaration, or"a realm of pure possibility whence configurations of ideas and relations may arise" (V. Turner, 1995, p. 97). This incongruity in the past and the present requires the inhabitants to confront tensions and contemplate a highly personal tentative resolution. "Coming to know" emerges from integrating an experiential frame of reference developed in the practicum with the troublesome knowledge presented in the liminal space.

\section{REFERENCES}

Beard, C., \& Wilson, J.P. (2006). Experiential learning: A best practice handbook for educators and trainers. Kogan Page.

Britzman, D. (2003). Practice makes practice: A critical study of learning to teach. SUNY Press.

Britzman, D. (2007). Teacher education as uneven development: Toward a psychology of uncertainty. International Journal of Leadership in Education, 10(1), 1-12. https://doi.org/10.1080/13603120600934079

Conroy, J.C. (2004). Betwixt and between: The liminal imagination, education and democracy. Peter Lang.

Cook-Sather, A. (2006). Newly betwixt and between: Revising liminality in the context of a teacher preparation program. Anthropology \& Education Quarterly, 37(2), 110-127. Retrieved from http://www.jstor.org/stable/3805061

Dacome, L. (2004). Noting the mind: Commonplace books and the pursuit of the self in eighteenthcentury Britain. Journal of the History of Ideas, 65(4), 603-625. https://doi.org/10.1353/jhi.2005.0013

Eddy, M.D. (2010). Tools for reordering: Commonplacing and the space of words in Linnaeus's Philosophia Botanica. Intellectual History Review, 20(2), 227-252. https://doi.org/10.1080/17496971003783773

Gadamer, H-G. (2004). Truth and method. Continuum Books.

Heading, D., \& Loughlin, E. (2018). Lonergan's insight and threshold concepts: Students in the liminal space. Teaching in Higher Education, 23(6), 657-667. https://doi.org/10.1080/13562517.2017.1414792

Huebner, D. (1999). The lure of the transcendent: Collected essays by Dwayne Huebner (V. Hillis \& W. Pinar, Eds.). Routledge.

Jardine, D. (2006). On hermeneutics: "Over and above our wanting and doing." In J. Kincheloe \& K. Tobin (Eds.), Doing educational research: A handbook (pp. 269-288). Sense Publishers.

Levin, N. (n.d.). Is it time for a graceful exit? Nancy Levin. Retrieved from https://nancylevin.com/is-ittime-for-a-graceful-exit

Lonergan, B.J.F. (1992). Insight: A study of human understanding (5th ed.; F. Crowe \& R. Doran, eds.).University of Toronto Press. (Original work published 1957)

Lutterman-Aguilar, A., \& Gingerich, O. (2002). Experiential pedagogy for study abroad: Educating for global citizenship. Frontiers: The Interdisciplinary Journal of Study Abroad, 8, 41-82. https://doi.org/10.36366/frontiers.v8i1.94

Oxford Review. (n.d.). Phronesis. In Oxford review encyclopedia of terms. Retrieved June, 11, 2021, from https://www.oxford-review.com/oxford-review-encyclopaedia-terms/phronesis-definitionmeaning/

Singh, J. (2020). Betwixt-and between: Reflections on liminality and loss from a second generation Canadian. In C. Cook, L. Goldbeck, \& L. Tira-Dimangondayao (Eds.), Beyond hospitality: Migration, multiculturalism and the church (pp. 112-120). Tyndale Academic Press.

Smith, D. (1999). Pedagon. Peter Lang.

Todd, S. (2014). Between body and spirit: The liminality of pedagogical relationships. Journal of Philosophy of Education, 48(2), 231-245. https://doi.org/10.1111/1467-9752.12065 
Trepanier, L. (2015, January 12). From the multiversity: Plato. Front Porch Republic. Retrieved from https://www.frontporchrepublic.com/2015/01/multiversity-plato/

Turner, E. (2012). Communitas: The anthropology of collective joy. Palgrave Macmillan.

Turner, V. (1969). The ritual process: Structure and anti-structure. Aldine.

Turner, V. (1974). Liminal to liminoid, in play, flow, and ritual: An essay in comparative symbology. Rice Institute Pamphlet - Rice University Studies, 60(3), 53-92. Retrieved from https://hdl.handle.net/1911/63159

Turner, V. (1981). Social dramas and stories about them. In W.J.T. Mitchell (Ed.), On narrative (pp. 137164). University of Chicago Press.

Turner, V. (1995). The ritual process: Structure and anti-structure. Walter De Gruyer.

Van Gennep, A. (1909). The rites of passage. Routledge.

von Heyking, J. (2017, November 14). Periagoge: Liberal education in the modern university. VoegelinView. Retrieved from https://voegelinview.com/periagoge-liberal-education-modernuniversity/

Willson, R. (2019). Transitions theory and liminality in information behaviour research: Applying new theories to examine the transition to early career academics. Journal of Documentation, 75(4), 838-856. https://doi.org/10.1108/JD-12-2018-0207 